\title{
Perencanaan dan Pengendalian Jadwal Pembuatan Gambar Desain dan Produksi Pembangunan Kapal Baru Dengan Metode Simulasi
}

\author{
Mohammad Habibi, dan Triwilaswandio Wuruk Pribadi \\ Departemen Teknik Perkapalan, Fakultas Teknologi Kelautan, Institut Teknologi Sepuluh Nopember \\ (ITS) \\ e-mail: triwilas@na.its.ac.id
}

\begin{abstract}
Abstrak-Tujuan utama dari penelitian ini adalah melakukan perencanaan dan pengendalian jadwal pembuatan gambar desain dan produksi pembangunan kapal baru dengan metode simulasi. Pertama, dilakukan survey untuk mengidentifikasi jenis-jenis gambar basic design dan gambar produksi kapal tug boat. Kedua ditentukan jumlah staf desain yang dibutuhkan untuk membuat basic design dan gambar produksi. Ketiga, dilakukan perencanaan dan pengendalian jadwal pembuatan gambar basic design dan gambar produksi dengan metode simulasi menggunakan microsoft project. Terakhir, diestimasikan biaya pembuatan basic design dan gambar produksi berdasarkan hasil simulasi. Dari studi ini, didapatkan hasil bahwa proses pengerjaan basic design dan gambar produksi pada kodisi optimis menggunakan 23 staf membutuhkan waktu penyelesaian 98 hari, sedangkan dengan 28 staf membutuhkan waktu 79 hari. Pengerjaan basic design dan gambar produksi pada kondisi pesimis menggunakan 23 staf desain memerlukan waktu 139 hari (6 bulan 10 hari) sedangkan proses desain dengan 28 staf memerlukan waktu 119 hari (5 bulan 11 hari). Untuk mendesain kapal tug boat $2 \times 1200$ HP dalam waktu 6 bulan memerlukan staf desain sebanyak 28 orang dengan total 13.440 jam orang.
\end{abstract}

Kata Kunci-Basic Design, Gantt Chart, Metode Simulasi, Tug Boat.

\section{PENDAHULUAN}

$\mathrm{I}$ NDONESIA sebagai negara maritim dengan 17.000 pulau yang dipisahkan oleh lautan yang luas menyebabkan ketimpangan dalam pembangunan maupun distribusi barang terutama didaerah timur. Hal tersebut memacu pemerintah untuk membuat perencanaan pembangunan maritim yang disebut dengan tol laut Indonesia untuk periode perencanaan pembangunan 2015 sampai 2019.

Berdasarkan data yang dihimpun dari menteri perhubungan tahun 2016, pemerintah merencanakan pembangunan untuk pengadaan kapal niaga untuk tahun 2015 hingga 2019 dengan nilai investasi mencapai 101,704 triliun rupiah, sedangkan untuk pengadaan kapal patroli pemerintah merencanaan anggaran biaya dengan total nilai investasi 6,048 triliun rupiah. Rencana pembangunan dibidang maritim tersebut berdampak positif terhadap pertumbuhan industri maritim baik galangan kapal maupun konsultan maritim.
Meningkatnya kebutuhan kapal memicu konsultan desain kapal dan galangan kapal untuk memperbaiki manajemen pelaksanaan proyek sehingga penyelesaian proyek dapat diselesaikan dengan baik dan tepat waktu. Pelaksanaan proyek yang baik dan tepat waktu dapat mengangkat nama perusahaan sehingga menjadi perusahaan yang terpercaya untuk mengerjakan proyek pembangunan kapal baik dari pemerintah maupun swasta.

Permasalahan yang dialami oleh suatu konsultan desain kapal yang baru adalah sulitnya mengestimasikan waktu penyelesaian proyek dan biaya yang dibutuhkan untuk meyelesaikan proyek desain kapal yang akan dilaksanakan karena minimnya data historis pelaksanaan proyek mendesain kapal. Untuk mendapatkan waktu estimasi penyelesaian proyek dan biaya yang dibutuhkan untuk menyelesaikan proyek pembuatan gambar desain maka dibutuhkan perencanaan dan pengendalian jadwal pembuatan gambar desain dengan mesimulasikannya menggunakan gantt chart dengan bantuan program komputer.

\section{STUDI LITERATUR}

\section{A. Proses Pembangnan Kapal Baru}

Kapal memiliki beberapa tahapan pembangunan antara lain

1. Tender proyek pembangunan kapal

2. Pembuatan gambar desain

3. Pengadaan barang

4. Pembuatan kapal di galangan (produksi)

5. Test and trial

6. Delivery

Pembuatan gambar desain memiliki implikasi pada tahap pengadaan barang, produksi dan pengiriman kapal. Pembuatan gambar desain yang mengalami keterlambatan dalam penyelesaiannya dapat menyebabkan keterlambatan dalam proses pengiriman, hal tersebut akan menyebabkan kerugian finansial baik oleh desain konsultan, galangan, maupun pemilik kapal.

\section{B. Tahap Pembuatan Gambar Desain}

Pembuatan gambar desain terdiri dari empat tahapan yaitu 
basic design, fuctional design, transitional design, dan work instruction drawing [1]. Basic Performance merupakan tahapan proses mendesain kapal berdasarkan spesifikasi kapal yang pesan oleh ship owner. Hasil dari basic performance adalah general arrangement dan lines plan namun juga dapat mencakup stabilitas dan kecepatan kapal.

Basic design merupakan proses perhitungan dan pembuatan desain sistem pada kapal secara utuh, seperti construction profile, engine room layout, dan lain sebagainya. Fuctional design merupakan proses mendesain sistem utama penunjang operasional kapal, seperti sistem balas, sistem bahan bakar, sistem kemudi dan sebagainya.

Transitional design merupakan tahapan untuk pembuatan gambar detail kapal berdasarkan sistem yang telah di buat pada fuctional design. Selain pembuatan detail gambar pada tahap fuctional design juga dilakukan perhitungan atau estimasi material yang akan digunakan untuk membangun kapal tersebut.

Work instruction drawing merupakan tahapan pembuatan gambar untuk keperluan proses produksi pada pembangunan kapal yang nantinya gambar tersebut akan didistribusikan ke bengkel-benkel produksi.

\section{Jenis-jenis gambar desain}

Gambar desain sendiri terdiri dari 4 bagian, antara lain hull construction, hull outfitting and interior, machinery outfitting dan electrical and electronic outfitting. Hul construction berisi gambar-gambar konstruksi lambung dan gading-gading kapal. hull outfitting merupakan gambar yang berisi tentang perlengakapan-perlengkapan dikapal baik keselamat maupun perlengakapan untuk operasional. Machinery outfitting berisi gambar-gambar desain keseuluruhan sistem yang ada di ruang mesin kapal serta gambar-gambar desain untuk perpipaan. Electrical and elecrtronic outfitting merupakan gambar desain yang berisi sistem sistem kelistrikan dan elektronik di kapal baik untuk pencahayaan (lighting) sistem otomasi maupun sistem kenavigasian.

\section{Perencanaan dan Pengendalian Produksi}

Perencanaan merupakan suatu kegiatan atau proses penganalisisan dan pemahaman sistem, penyusunan konsep dan kegiatan yang akan dilaksanakan untuk mencapai tujuantujuan demi masa depan yang baik [2]. Pengendalian produksi (production control) merupakan suatu kegiatan atau metode yang digunakan oleh suatu perusahaan untuk mengelola, mengatur, mengkoordinir dan mengarahkan faktor-faktor produksi (peralatan, bahan baku, mesin, modal, tenaga kerja) pada aliran proses produksi untuk memberikan hasil yang seoptimal mungkin dengan biaya yang seminimal mungkin dan dalam waktu produksi yang secepatnya. Pengendalian produksi dimaksudkan untuk mendayagunakan sumber daya produksi yang terbatas secara efektif, terutama dalam usaha memenuhi permintaan konsumen dan menciptakan keuntungan bagi perusahaan. Sumber daya produksi mencakup fasilitas produksi, tenaga kerja dan bahan baku [3]. Prencanaan dan pengendalian produksi digunakan untuk membuat perencaan produksi dan sekaligus mengevaluasi hasil dari perencanaan sehingga dalam proses pelaksanaan produksi dapat terealisasikan dengan baik.

\section{E. Network Planning}

Network Planning merupakan alat untuk mengkoordinasikan berbagai macam pekerjaan yang ada satu sama lainnya bebas dan atau saling bergantung berdasarkan pertimbangan sumber daya yang digunakan, logika proses yang berlangsung dan hasil proses itu sendiri [4]. Keluaran network planning pada suatu proyek yaitu informasi mengenai kegiatan-kegiatan yang ada pada network diagram, sumber daya yang digunakan pada proyek tersebut serta inforamsi mengenai jadwal pelaksanaannya

\section{F. Tinjauan Umum Kapal Tunda}

Kapal tunda merupakan jenis kapal yang digunakan untuk melakukan pergerakan dan manuver yang cepat dan memiliki stabilitas yang baik guna untuk menarik atau mendorong kapal lainnya di pelabuhan, laut lepas, sungai atau melalui terusan. Persyaratan utama yang harus dimiliki kapal tunda yaitu kemampuan tarik yang tinggi.

Kapal tunda dirancang untuk melakukan pekerjaan berat yaitu membantu kapal lainnya baik meskipun pada kondisi arus yang kuat, berangin dan bergelombang. Kapal tunda memiliki karakteristik antara lain:

1. Memiliki daya mesin yang tinggi (high horse power)

2. Memiliki kemampuan manuver yang cepat meskipun dalam kecepatan laju rendah

3. Diameter baling-baling (propeller) yang besar

4. Memiliki penampang kemudi yang lebar

5. Memiliki perlengkapan mesin tambat

6. Terdapat power capstan

7. Dilengkapi dengan towing points

8. Pada lambung haluannya dilengkapi dengan bow thruster.

9. Memiiki fasilitas mesin derek di geladaknya (deck crane)

\section{METODOLOGI PENELITIAN}

Berikut ini adalah tahap metodologi penelitian yang dilakukan :

\section{A. Identifikasi Masalah}

Pada tahap identifikasi maslah peneliti menemukan suatu kasus dimana proses desain memiliki dampak besar terhadap pembagunan kapal baik pada proses pengadaan barang maupun proses produksi. Oleh karena itu perlu dilakukan perencanaan yang tepat sehingga proses desain bisa berjalan dengan baik dan selesai tepat waktu serta dapat menekan biaya untuk pembuatan gambar desain itu sendiri.

\section{B. Perumusan masalah}

Dari studi atau pengamatan yang dilakukan peneliti menemukan permasalah bagaimana cara melakukan perencanaan dan pengendalian gambar desain yang tepat pada pembuatan kapal baru. Permasalah selanjutnya yaitu bagaimana menetukan jumlah engineer dan drafter untuk pembuatan gambar desain dan apa saja dampak yang ditimbulkan akibat keterlambatan dalam pembuatan gambar desain. 


\section{Studi Literatur}

Studi literatur dilakukan guna untuk menunjang dalam melaksanakan penelitian ini. Dalam tahapan ini studi literatur yang digunakan yaitu mengenai karakter kapal tug boat, studi mengenai jenis jenis gambar desain serta tahapnnya untuk mendefinisikan hubungan antar entitas dalam gambar desain. Studi lainnya yaitu mengenai estimasi biaya produksi untnuk menentukan besar biaya yang dibutuhkan untuk pembuatan gambar desain

\section{Pengumpulan dan Pengolahan Data}

Data yang dihimpun untuk menunjang penelitian ini adalah berupa master schedule pembangunan kapal tug boat untuk menentukan lama waktu pengerjaan desain dan produksi. Selain itu data yang dibutuhkan yaitu macam-macam gambar desain yang telah didefinisikan berdasarkan tahapan dan kelompoknya. Data lama waktu pengerjaan gambar desain dengan melakukan kuisioner terhadap engineer dan drafter yang telah berpengalaman dibidang desain dan engineering untuk menetukan jam orang yang dibutuhkan untuk pembuatan gambar desain dan juga diguakan untuk menghitung kebutuhan staf desain sebelum dilakukannya simulasi.

\section{E. Simulasi}

Untuk melakukan perencanaan dan pengendaliannya dibutuhkan simulasi dengan menggunakan komputer untuk meminimalisir risiko keterlambatan dalam proses pembuatan gambar desain. Simulasi ini menggunakan program komputer yang ditunjukkan dalam bentuk gantt chart

\section{F. Analisis dan Pembahasan}

Hasil yang didapatkan dari proses simulasi selanjutnya akan dilakukan analisis mengenai waktu pembuatan gambar desain, jumlah engineer dan drafter yang digunakan, biaya yang dibutuhkan serta dampak yang terjadi akibat keterleambatan pembuatan gambar desain.

\section{G. Kesimpulan dan saran}

Tahap menarik kesimpulan merupakan tahap terakhir dari penulisan penelitian. Kesimpulan didapatkan berdasarkan hasil analisis dan pembahasan yang telah diuraikan pada bab sebelumnya. Selain kesimpulan penulis juga memberikan saran yang diharapkan dapat membantu pembaca dalam mengambil keputusan yang berhubungan dengan yang diteliti pada karya tulis ini.

\section{URAIAN PENELITIAN}

\section{A. Data Utama Kapal}

Kapal yang diteliti merupakan kapal jenis tug boat dengan panjang total kapal (LOA) 29 meter, panjang garis air (LWL) 25,64 m, lebar (B) $9 \mathrm{~m}$, tinggi geladak utama kapal (H) 4,5 m, sarat air pada kapal (T) 3,5 m, kecepatan dinas kapal (Vs) 12 knot, dan daya mesin kapal 2 x 1200 HP (2 x 894 kW $)$

\section{B. Penentuan Jumlah Staf Desain}

Menentukan jumlah staf desain didasarkan pada jumlah jam orang yang dibutuhkan untuk pembuatan basic design dan gambar produksi. Untuk mendapatkan jumlah staf desain pada Tabel 1 menggunakan persamaan berikut ini,

$$
\text { Jumlah staf }=\mathrm{JO} /(60 * 8)
$$

Dimana

60 : target penyelesaian selama 60 hari

8 : beban kerja perhari adalah 8 jam

Kebutuhan jam orang (JO) untuk pembuatan basic design dan gambar produksi dihitung berdasarkan Persamaan 2 dibawah ini,

$$
\mathrm{JO}=\underline{\text { waktu pengerjaaan }}
$$

dimana

JO : jumlah jam orang

Staf : jumlah staf yang dibutuhkan untuk penyelesaian tiap basic design ataupun gambar produksi (orang)

8 : beban kerja karyawan desain setiap hari adalah selama 8 jam

Tabel 1.

\begin{tabular}{|c|c|c|c|c|}
\hline \multicolumn{5}{|c|}{ Basic Performance } \\
\hline No & Staf & $\begin{array}{l}\text { Kebutuhan } \\
\text { (JO) }\end{array}$ & $\begin{array}{l}\text { Kode } \\
\text { Staf }\end{array}$ & $\begin{array}{c}\text { Jumlah } \\
\text { Staf }\end{array}$ \\
\hline 1 & Junior Engineer & 312 & JE BP & 1 \\
\hline \multicolumn{5}{|c|}{$\begin{array}{l}\text { Hull Construction } \\
\end{array}$} \\
\hline No & Staf & $\begin{array}{l}\text { Kebutuhan } \\
\text { (JO) }\end{array}$ & $\begin{array}{l}\text { Kode } \\
\text { Staf }\end{array}$ & $\begin{array}{l}\text { Jumlah } \\
\text { Staf }\end{array}$ \\
\hline 1 & Basic Design & 56 & JE HC & \multirow{3}{*}{1} \\
\hline 2 & Key Plan & 80 & JE HC & \\
\hline \multirow{2}{*}{3} & \multirow{2}{*}{ Yard Plan } & 88 & JE HC & \\
\hline & & 336 & Dr HC & 1 \\
\hline 4 & Production Drawing & 680 & Dr HC & 2 \\
\hline \multicolumn{5}{|c|}{ Hull Outfitting\&Interior } \\
\hline No & Staf & $\begin{array}{l}\text { Kebutuhan } \\
\text { (JO) }\end{array}$ & $\begin{array}{l}\text { Kode } \\
\text { Staf }\end{array}$ & $\begin{array}{c}\text { Jumlah } \\
\text { Staf }\end{array}$ \\
\hline 1 & Basic Design & 16 & JE HO & \multirow{3}{*}{1} \\
\hline 2 & Key Plan & 72 & JE HO & \\
\hline \multirow{4}{*}{3} & \multirow{4}{*}{ Yard Plan } & 200 & JE HO & \\
\hline & & 264 & JE ID & 1 \\
\hline & & 456 & Dr HO & 1 \\
\hline & & 344 & Dr ID & 1 \\
\hline 4 & Production Drawing & 608 & Dr & 2 \\
\hline \multicolumn{5}{|c|}{ Machinery Outfitting } \\
\hline No & Staf & $\begin{array}{l}\text { Kebutuhan } \\
\text { (JO) }\end{array}$ & $\begin{array}{l}\text { Kode } \\
\text { Staf }\end{array}$ & $\begin{array}{c}\text { Jumlah } \\
\text { Staf }\end{array}$ \\
\hline 1 & Basic Design & 24 & JE MO & \multirow{3}{*}{2} \\
\hline 2 & Key Plan & 248 & JE MO & \\
\hline \multirow{2}{*}{3} & \multirow{2}{*}{ Yard Plan } & 632 & JEMO & \\
\hline & & 688 & Dr MO & 2 \\
\hline 4 & Production Drawing & 624 & Dr MO & 2 \\
\hline \multicolumn{5}{|c|}{ Electrical \&Electronic Outfitting } \\
\hline No & Staf & $\begin{array}{c}\text { Kebutuhan } \\
\text { (JO) }\end{array}$ & $\begin{array}{c}\text { Kode } \\
\text { Staf }\end{array}$ & $\begin{array}{c}\text { Jumlah } \\
\text { Staf }\end{array}$ \\
\hline 1 & Basic Design & 24 & JE EEO & \multirow{3}{*}{2} \\
\hline 2 & Key Plan & 80 & JE EEO & \\
\hline \multirow{2}{*}{3} & \multirow{2}{*}{ Yard Plan } & 632 & JE EEO & \\
\hline & & 240 & DrEEO & 1 \\
\hline 4 & Production Drawing & 272 & DR EEO & 1 \\
\hline \multicolumn{5}{|c|}{ Senior Engineer } \\
\hline No & Departemen & $\begin{array}{c}\text { Kebutuhan } \\
\text { (JO) }\end{array}$ & $\begin{array}{l}\text { Kode } \\
\text { Staf }\end{array}$ & $\begin{array}{c}\text { Jumlah } \\
\text { Staf }\end{array}$ \\
\hline 1 & Basic Performance & & \multirow{3}{*}{ SE NA } & \multirow{3}{*}{1} \\
\hline 2 & Hull Construction & & & \\
\hline 3 & Hull Outfitting & & & \\
\hline 4 & Machinery Outfitting & & \multirow{2}{*}{ SE ME } & \multirow[b]{2}{*}{1} \\
\hline 5 & EEO & & & \\
\hline
\end{tabular}

Perhitungan penentuan jumlah staf desain

Pada tabel 1 kode staf JE merupakan junior engineer, SE merupakan senior engineer dan DR adalah drafter. Jumlah 
senior engineer yang dibutuhkan sebagai supervisor untuk melakukan kontrol dan pengawasan terhadap proses basic design adalah sebanyak 2 orang yang terdiri dari 1 orang mengawasi pekerjaan basic performance, hull contruction, hull outfitting dan 1 orang mengawasi pekerjaan machinery outfitting, dan electrical electronic outfitting.

Total junior engineer yang dibutuhkan untuk pekerjaan basic performance 1 orang, hull construction 1 orang, hull outfitting 1 orang, interior design 1 orang, machinery outfitting 2 orang, dan electrical electronic outfitting 2 orang. Jumlah drafter yang dibutuhkan untuk penyelesaian gambar produksi hull construction 3 orang, hull outfitting 3 orang, interior design 1 orang, machinery outfitting 4 orang, dan electrical electronic outfitting 2 orang. Total kebutuhan staf junior engineer adalah 8 orang dan drafter sebanyak 13 orang.

\section{Hasil Simulasi}

Pada kondisi pesimis (terdapat revisi gambar desain pada proses approval biro klasifikasi), didapatkan hasil simulasi pembuatan gambar desain dengan 23 staf, pembuatan gambar desain terselesaikan dalam waktu 139 hari yang mana waktu penyelesaiannya yaitu tanggal 13 Juli 2017. Hasil simulasi dengan menggunakan 28 staf desain diketahui bahwa gambar desain terselesaikan dalam waktu 119 hari yaitu pada tanggal 15 Juni 2017. Berdasarkan ketetapan waktu penyelesaian gambar desain yang terdapat dalam master scheedule adalah 6 bulan yang jatuh pada tanggal 1 juli 2017 maka simulasi dengan menggunakan 23 orang staf desain mengalami keterlambat selama 10 hari.

Pada kondisi optimis (tidak ada revisi gambar desain saat proses approval biro klasifikasi), penyelesaian gambar desain membutuhkan waktu 98 hari dimana selesai pada tanggal 17 Mei 2017 untuk 23 staf desain. Simulasi dengan 28 staf desain pada kondisi optimis didapatkan lama pegerjaaan gambar desain adalah 79 hari yang mana gambar desain selesai pada tanggal 20 April 2017

\section{Estimasi Biaya Pembuatan Gambar Desain}

Biaya yang dikeluarkan untuk pembuatan gambar desain terdiri dari biaya langsung dan biaya tidak langsung. Biaya langsung terdiri dari biaya belanja pegawai/staf desain dan material printing, software dan perlengkapan desain. Biaya tidak langsung terdiri dari biaya operasional perusahaan, biaya penggunaan bangunan dan pajak. Perhitungan biaya desain dihitung berdasarkan pengeluaran tiap bulan yang diterima oleh konsultan desain hingga proyek terselesaikan. Perhitungan biaya desain untuk 23 staf desain disajikan berdasarkan Tabel 2 dan estimasi baya desain pada Tabel 3 .

Estimasi biaya desain pada tabel 2 merupakan estimasi biaya desain utnuk penggunaan 23 staf desain. Berdasarkan tabel 2 didapatkan hasil estimasi biaya desain untuk pembuatan kapal tug boat $2 \times 1200 \mathrm{HP}$ dengan 23 staf desain adalah sebesar Rp 598.241.600,00.

Perhitungan biaya untuk 28 staf desain disajikan dalam Tabel 3. Berdasarkan estimasi biaya desain pada Tabel 3 diketahui bahwa biaya desain untuk pembuatan kapal tug boat dengan 28 staf desain adalah sebesar Rp 587.441.700,00

Tabel 2.

Estimasi biaya desain 23 staf desain

\begin{tabular}{|c|c|c|c|c|c|c|}
\hline No & Jenis Pembiayaan & Harga Satuan & Satuan & volume & Satuan & Jumlah \\
\hline 1 & Belanja Pegawai & Rp $132.000 .000,00$ & perbulan & 3,5 & bulan & Rp 462.000.000,00 \\
\hline 2 & Software & Rp 9.916.666,67 & Perbulan & 3,5 & bulan & Rp39.666.666,67 \\
\hline 3 & Percetakan & Rp 1870.811,31 & Perbulan & 3,5 & bulan & Rp 7.483.245,22 \\
\hline 4 & Komputer & Rp 6.250.000,00 & Perbulan & 3,5 & Bulan & $\operatorname{Rp} 25.000 .000,00$ \\
\hline 5 & Laptop & $\operatorname{Rp} 750.000,00$ & Perbulan & 3,5 & Bulan & Rp 3.000.000,00 \\
\hline 6 & Kantor Konsultan & $\operatorname{Rp} 3.645 .833,33$ & Perbulan & 3,5 & Bulan & $\operatorname{Rp} 14.583 .333,33$ \\
\hline 7 & PBB & $\operatorname{Rp} 72.916,67$ & Perbulan & 3,5 & Bulan & $\operatorname{Rp} 291.666,67$ \\
\hline 8 & $\begin{array}{l}\text { Biaya Operasional } \\
\text { Kantor }\end{array}$ & Rp 3.600.000,00 & Perbulan & 3,5 & Bulan & Rp $14.400 .000,00$ \\
\hline 9 & $\begin{array}{l}\text { Biaya Perawatan } \\
\text { Bangunan }\end{array}$ & $\operatorname{Rp} 2.729 .166,67$ & Perbulan & 3,5 & Bulan & Rp 10.916.666,67 \\
\hline 10 & Biaya Kebersihan & Rp $4.500 .000,00$ & Perbulan & 3,5 & Bulan & Rp 21.000.000,00 \\
\hline & \multicolumn{5}{|c|}{ Total } & Rp 598.341.578,56 \\
\hline
\end{tabular}

Tabel 3.

Estimasi biaya desain 28 staf desain

\begin{tabular}{|l|l|l|l|l|l|l|}
\hline No & Jenis Pembiayaan & $\begin{array}{c}\text { Harga Satuan } \\
(\text { Rp) }\end{array}$ & Satuan & volume & Satuan & Jumlah (Rp) \\
\hline $\mathbf{1}$ & Belanja Pegawai & 158.000 .000 & perbulan & 3 & bulan & $474.000 .000,00$ \\
\hline $\mathbf{2}$ & Software & $9.916 .666,67$ & Perbulan & 4 & bulan & $29.750 .000,00$ \\
\hline $\mathbf{3}$ & Percetakan & $1870.811,31$ & Perbulan & 4 & bulan & $6.110 .933,67$ \\
\hline $\mathbf{4}$ & Komputer & $6.250 .000,00$ & Perbulan & 4 & Bulan & $1.8750 .000,00$ \\
\hline $\mathbf{5}$ & Laptop & $750.000,00$ & Perbulan & 4 & Bulan & $2.250 .000,00$ \\
\hline $\mathbf{6}$ & Kantor Konsultan & $3.645 .833,33$ & Perbulan & 4 & Bulan & $10.937 .500,00$ \\
\hline $\mathbf{7}$ & PBB & $72.916,67$ & Perbulan & 4 & Bulan & $218.750,00$ \\
\hline $\mathbf{8}$ & $\begin{array}{l}\text { Biaya Operasional } \\
\text { Kantor }\end{array}$ & $3.600 .000,00$ & Perbulan & 4 & Bulan & $19.200 .000,00$ \\
\hline $\mathbf{9}$ & $\begin{array}{l}\text { Biaya Perawatan } \\
\text { Bangunan }\end{array}$ & $2.729 .166,67$ & Perbulan & 4 & Bulan & $8.187 .500,00$ \\
\hline $\mathbf{1 0}$ & Biaya Kebersihan & $4.500 .000,00$ & Perbulan & 4 & Bulan & $18.000 .000,00$ \\
\hline & \multicolumn{7}{|c|}{ Total } & & & $587.404 .683,67$ \\
\hline
\end{tabular}

\section{KESIMPULAN}

Metode simulasi dapat digunakan untuk melakukan perencanaan dan pengendalian pembuatan gambar desain. Didapatkan bahwa 23 staf desain membutuhkan waktu 139 hari untuk menyelesaikan gambar desain dengan biaya sebesar Rp 598.341.600,00. Simulasi dengan 28 staf desain didapatkan penyelesaian gambar desain selama 119 hari dengan biaya total $\mathrm{Rp}$ 587.404.700,00. Akibat keterlambatan dalam pembuatan gambar desain selama 10 hari, pengerjaan gambar desain yang melibatkan 23 staf mengalami kerugian sebesar Rp 66.100.000,00 sehingga total biaya desainnya menjadi Rp 664.441.600,00. Hasil tersebut menunjukkan memperkerjakan 28 orang staf desain lebih efektif dibandingkan 23 staf dengan jumlah JO sebesar 13.440 JO.

\section{DAFTAR PUSTAKA}

[1] R. L. Storch, ship Production (2 ed.). USA: Cornell Maritime, 1995.

[2] S. Notoatmodjo, Ilmu Kesehatan Masyarakat (Perinsi-perinsip Dasar) (2nd ed.). Jakarta: Rineka Cipta, 2003. 
[3] A. Ahyari, Manajemen Produksi "Pengendalian Produksi," 4th ed. Yogyakarta: BPFE, 2002.

[4] T. H. Ali, Prinsip-Perinsip Network Planning. Jakarta: Gramedia Media Pustaka, 1992. 